\title{
Postmodernizm ve Özne Bağlamında Dövüş Kulübü Filminin Değerlendirilmesi
}

\author{
DOI: $10.26466 /$ opus.676541
}

\author{
Anıl Kaan Uçar * \\ * Öğr. Gör. Dr, Ordu Üniversitesi Ulubey M.Y.O. Gazetecilik ve Habercilik Bölümü/Ordu/Turkey \\ E-Posta: anilkaanucar@gmail.com \\ ORCID: $0000-0002-8311-741 X$ \\ Öz
}

Modernizm, özne bölünmelerine, ekonomik eşitsizliklere, kimliklerin zayıflayarak parçalanmasına, kentleşme sonucu zaman ve mekân olgularının ortadan kalkmasına zemin hazırlamıştır. Bu gelişmelerin merkezinde kendisine yer bulan postmodernizm, tüm sanat dalların etkisi altına almıştır. Özellikle sinema çerçevesinde 1990'lar, postmodern filmlerin yayginlaşmaya başladığı yıllar olmuştur. Modernizmin yarattığı toplumsal ortama karşı; şiddet, parçalanmışlık, kargaşa ve cinselliğin aktarılması noktasında diğer filmlerin ötesine geçen postmodern filmler, tür olarak net bir biçimde konumlandirllamasa da, hem Hollywood hem de avangard filmlerden özellikler taşımaktadır. Dövüş Kulübü verdiğgi mesajlar ile avangard sinemaya benzerlik gösterirken işaret ettiği kaos ve anlatı tarzıyla da postmodern filme yakın durmaktadır. Çalışmanın konusunu oluşturan Dövüş Kulübü üzerine yapılan pek çok çalışma, filmin bir sistem eleştirisi olduğu üzerinden hareket etmiştir. Bu çalışmada ise Dövüş Kulübü, babasız büyümüş çocuklarm postmodern süreç içerisinde özne olma mücadeleleri ve toplumsal atmosferin yarattığı ruhsal problemlere dair verilen mesajlar çerçevesinde çözümlenmeye çalışılmıştır. Çalışmada, öncelikle postmodernizm kavramı; Baudrillard, Lyotard, Jameson ve Harvey'in bakış açısıyla ele alınmış ve bu bilgiler ışı̆̆ında postmodern film üzerine yoğunlaşılmıştır. Genellikle tüketim toplumu çerçevesinde değerlendirilen Dövüş Kulübü, derinlikli anlatısı ile bir özne kaosuna işaret etmektedir. Bu kaosu açımlamayı amaç edinen bu çalışma kapsamında Dövüş Kulübü filmi psikanaliz çerçevesinde çözümlenmiştir. Sonuç olarak Dövüş Kulübü filmi çerçevesinde postmodernizm, modern karşıtı bir durum olmanın ötesinde özne olma ya da olamama meselesine karşılık gelmektedir.

Anahtar Kelimeler: Postmodernizm, Özne, Postmodern Film, Dövüş Kulübü 


\title{
Postmodernism and Evaluation of the Film of Fight Club in the Context of Subject
}

\begin{abstract}
Modernism has paved the way for subject divisions, economic inequalities, weakening of identities and the disappearance of time and space facts as a result of urbanization. Postmodernism, which has taken its place in the center of these developments, has influenced all branches of art. Especially in the context of cinema, 1990s were the years when postmodern films began to become widespread. At the point of transmitting violence, fragmentation, turmoil and sexuality against the social environment created by modernism, postmodern films that go beyond other films have features from both Hollywood and avant-garde films, although they cannot be clearly positioned in genre. While the Fight Club is similar to avant-garde cinema with its messages, it stands close to postmodern film with its chaos and narrative style. Many studies on the Fight Club that constitute the subject of the study have acted on the fact that the movie is a system criticism. In this study, Fight Club was tried to be resolved within the framework of messages given about the struggles of being a subject in the postmodern process of children who grew up without a father and the mental problems caused by the social atmosphere. In the study, primarily the concept of postmodernism; Baudrillard has been handled from the point of view of Lyotard, Jameson and Harvey, and in the light of this information, concentrated on postmodern film. The Fight Club, which is generally evaluated within the context of the consumer society, points to a subject chaos with its in-depth narrative. The Fight Club movie was analyzed within the framework of psychoanalysis within the scope of this study, which aims to explain this chaos. As a result, postmodernism, in the frame of the Fight Club movie, is about being a subject or not being more than an antimodern situation.
\end{abstract}

Keywords: Postmodernism, Subject, Postmodern Movie, Fight Club 


\section{Giriş}

Aydınlanmanın hükümranlığı, pozitivizm ve modernizmin çizdiği sınırlar ile sağlamlaşmıştır. İkinci Dünya Savaşı, pozitivizm sayesinde tarihin ürettiği en gelişmiş teknolojik olanakların kullanıldığı savaş olarak kayda geçerken, toplumsal anlamda derin izler bırakmıştır. Savaşın beraberinde getirdiği ekonomik problemler, pozitivizm ile modernizmin ve daha derinde de kapitalizmin sorgulanmasına neden olmuştur.

1960 'l y yllarda yaşanan toplumsal hareketler, modernizme karşı bir duruş niteliği taşırken postmodern sürecin de başlangıcını oluşturmuştur. Karışıklık, umutsuzluk, iletişimsizlik, güvensizlik ve şiddet temelli inançsızlık gibi olguları ortaya çıkaran modern dönem, postmodern dönemin habercisi olmuştur (Bayraktaroğlu ve Uğur, 2011, s.6).

Postmodernizmi açımlayan teorisyenlerin en önemlileri şüphesiz Baudrillard, Lyotard, Harvey ve Jameson'dır. Baudrillard ve Lyotard postmodernizme yeni iletişim teknolojilerinin yarattığı toplumsal ortam noktasında yaklaşırken, Harvey ve Jameson gibi neomarksist teorisyenler ise postmodern süreci; sermayenin küreselleşme aracı olarak yararlandığı bir homojenleştirme dönemi olarak değerlendirmiştir.

Çok kültürlülügü̈n yaygınlaşması, enformasyon akışının yoğunlaşması, kentleşmeye bağlı olarak zaman ve mekân olgularının ortadan kalkması gibi durumlara ortam hazırlayan modernizm, bireysel çerçevede özne olamama ya da kimlik sorunlarına yol açarken, küresel çerçevede de ulus devletlerin sınırlarının saydamlaşmasına ve milli kodların çözülmesine yol açmıştır. Tüm bu gelişmeler postmodern sürecin hızlanmasına zemin hazırlarken tasarım, mimarlık ve sanat gibi tüm entelektüel alanlar bu yeni dönemden yoğun bir biçimde etkilenmiştir. Dolayısıyla postmodernizm, kargaşa, şiddet ve parçalanmışlığa dayalı anlatılar ile sinemayı da etkisi altına alarak sanatlardaki dişavurumun önüne geçmiştir (Bayraktaroğlu ve Uğur, 2011, s.6).

1980'lerde etkisini sinema alanında hissettirmeye başlayan postmodernizm, 1990'lı yıllara gelindiğinde ise üretilen film örnekleriyle yoğun bir biçimde adından söz ettirmiştir. Postmodern özellikler taşıyan filmler, belirli bir öykü bütünlüğü takip etmeyerek klasik anlatıdan oldukça farklı bir yapıya bürünmüştür. Yeni Dalga gibi öyküyü kesintiye uğratması ya da bazı türlerinin mesaj kaygısı taşıması açısından postmodern filmler, melez bir tür 
olarak hem avangard hem Hollywood kökenli filmlerden izler taşımaktadır. Geleneksel anlatı biçimini taşıyan Hollywood filmlerinde izleyici, öyküyü kolay anlamakta ve öykünün kahramanlarıyla özdeşim kurabilmektedir. Avangard filmlerde ise, izleyicinin anlatıdaki mesajları algılaması ve kahramanla özdeşim kurması güçtür. Postmodern filmler tam bu iki anlatı yapısının ortasında, ikisinden de özellikler taşıyan bir tür olarak dikkat çekmektedir. Postmodern filmler, pastiş ve parodi unsurlarından yararlanarak, modern filmlerin anlatı yapılarına, kahramanlarına ve öykülerine sık sık gönderme yapmaktadır. Örneğin Tarantino, Ucuz Roman ve Reservuar Köpekleri filmlerinde, Hollywood'un Amerikan mafyası ve polisiye hikâyelerini karikatürize ederken, Yeni Dalga'nın en önemli temsilcisi Godard ise Serseri Aşıklar filmiyle, Hollywood'un mafya tipolojisine göndermede bulunmaktadır. Bu örnekler, postmodern filmlerin melez bir tür olduğunun önemli bir göstergesidir.

Bu çalışmanın konusunu oluşturan Dövüş Kulübü, postmodern bir film olarak nitelendirilmektedir. David Fincher'ın 1999 yllında çektiği Dövüş Kulübü filmini sadece kültür endüstrisi üzerinden okumak, filmin derinliğini kavrayamamak anlamına gelecektir. Filmdeki Anlatıcının ünlü bir Amerikan araç şirketinde (General Motors) sigortacı olması, kaza sonucu hayatını kaybeden insanların ailelerine şirketin kâr oranını düşürmemek kaydıyla ödeme yapması, tüketim toplumunun temel dinamiği olan hesaplanabilirlik ilkesiyle örtüşmektedir. Film sistemsel eleştiri taşıyan göndermelerinin yanında, özne olabilme mücadelesine dair psikolojik mesajlarıyla da dikkat çekmektedir. Dolayısıyla postmodernizmin öznesel kırılmalara neden olmasından hareketle bu kırılmaların sinemadaki yansımasına odaklanan çalışma, öncelikle "postmodernizm nedir?" sorusunun yanitını detaylandırmaktadır. Diğer yandan da postmodern filmlerin genel özelliklerine değinmektedir. Çalışma son noktada ise, postmodernizmin özne meselesi etrafındaki etkisi çerçevesinde bilinç ve bilinçdışı bağlamında Dövüş Kulübü filmini değerlendirmektedir.

\section{Postmodernizm Nedir?}

Postmodernizm, modernizmin çizdiği, aklı araçsallaştıran sınırların ortadan kalktığı bir akım mıdır? Modernizme bir başkaldırı mıdır? Spartacus gibi köle-efendi sömürüsüne karşı çıan bir devrimci midir? Yoksa tüm bunların 
aksine, modernizmin sınırları içerisinde ortaya çıkmış bir geç kapitalist dönem yansıması mıdır? Tüm bu sorular aslında, şu biçimde yanıtlanmaktadır: Harvey, Lyotard ve Jameson'a göre postmodernizm, modernizmden niteliksel olarak farklı ama onun çizdiği sınırlar çerçevesinde ortaya çıkmış bir durumdur.

Bu noktada kısaca modernizmi ele almak, onun içerisinde filizlenen postmodernizmin anlaşılır olabilmesi için önemli olacaktır. Modernizm en net karşılığıyla Aydınlanma Çağı'ndan başlayarak ulusal akımların da güçlendiği İkinci Dünya Savaşı'nın hemen sonrasına kadar geçen süreci kapsamaktadır. 18. yüzyılda Batı'da gelişim gösteren, toplumsal ve ekonomipolitik düzleme göndermede bulunan modernlik; günümüzde geleneksel düzenle karşıtlık içerisinde ilerlemeci, iktisadi ve yönetsel ussallaşmanın merkezine yerleşmektedir (Sarup, 1995, s.156; Featherstone, 1996, s. 21-22). Bireyin aklı ile her şeyin üstesinden gelebileceğini, tüketerek bireyselleşeceğini, çok çalışarak ve yarışarak da yükseleceğini öngören mekanik ve ilerlemeci bir nosyon olan modernizm, Max Weber ve çağdaşları için gelenekçi toplumsalın tam karşısında yer almaktadır. Kentleşme, modernleşme, metalaşma, endüstrileşme, kültürel farklılaşma, bireyselleşme ve sekülerleşme gibi süreçleri anlatan modernizm (Best ve Kellner, 2011, s.15), esasında bir homojenliğe yol açmıştır. Bu bütünleştirici anlayış; tüketim, teknoloji ve aşırı bireysellik gibi noktalarda ortaya çıarak toplumsalı da bu kodlar etrafında biçimlendirmiştir. Baudrillard, Harvey ve Lyotard gibi teorisyenlerin yaklaşımları da esasında toplumsalın bu dönüşümünü anlatma arzusunun bir yansımasını oluşturmaktadır. Çünkü postmodernizm, modernizmin birey ve toplum üzerindeki yansımalarının dışavurumuna karşlılk gelmektedir.

Lyotard'a göre (1994) postmodernizm, modernizmin bir parçasıdır. Jameson (1994) ve Harvey (1997)'ye göre ise postmodernizm, 1960'larda modern ve kültür karşıtı bir hareket olarak doğmuş, sonrasında üniversitelerde, sanat müzelerinde ve çeşitli akademik alanlarda kurumsallaşarak emperyalizmin içinde eriyen çok yönlü bir tepki haline gelmiştir. Dolayısıyla postmodernizmin 1960'larda esinlendiği devrimci ruh, emperyalist Amerikan kültürü içinde nesneleşerek etkisini yitirmiştir.

Harvey (1997), bu umutsuz yaklaşımı bir adım daha ileriye götürerek postmodernizmi, modernizmle keskin bir kopuş olarak değil postfordist dönemin kültürel boyutu olarak ele almaktadır. Ona göre postmodernizm 
kapitalizmden kopuş olarak ele alınmamalı tam aksine onu maskeleyen bir süreç olarak irdelenmelidir. Dolayısıyla postmodernizmi, modernizmin karşısında konumlandırmak son derece yanlış olacaktır.

Postmodernizmin kapitalizmin sınırları içerisinde ortaya çıtığını ifade eden Jameson da böyle bir yaklaşımın devrimci bir hareket olmayacağını belirtmiştir. Çünkü ona göre, ekonomik parametreler ve o parametrelerin oluşturduğu toplumsal sistemin içerisinde gelişen her süreç, aynı sistemin bir ürünü olmaktadır ya da zaman içinde sistem tarafından dönüştürülmektedir. Jameson postmodernizmin, bireysel öznenin ortadan yok olduğu ve bunun sonucunda da kişisel biçemin varlığını yitirdiği bir ortamda ortaya çıktığını vurgulamaktadır (Jameson, 1994, s.44-46). Sistemin yarattığı tüm olgu ve olaylara karşı bir güvensizlik durumunu da içerisinde taşıyan postmodernizm; Harvey'in, Jameson'ın ve özellikle de Baudrillard'ın vurguladığı gibi öznenin yok olduğu, taklitler, karmaşa ve yüzeysellikler barındıran sürecin içinde cereyan eden bir duruma karşılık gelmektedir.

Baudrillard (1998, s. 149-155)'e göre postmodernizm, simülasyonlar ile modellerin ve gerçek dünya ile görünen dünya arasındaki ayrımın silindiği teknolojik ve enformasyon biçimlerinin önemli rol oynadığı bir sürece denk gelmektedir. Baudrillard için modernizmin temel motivasyonu üretim faktörüyken postmodernizm; teknoloji ve tüketim temelinde bir illüzyonun yaratıldığı, taklitlerin egemen olduğu hipergerçek bir süreçtir. Bu durumda dünya kopyanın kopyası ve görüntülerin imlediği bir yanılsama haline gelmiştir. Bu yanılsama içerisinde gerçeği kaybetmiş olan birey de bir simülakrdır.

Özetle, Baudrillard, Harvey ve Jameson'a göre postmodernizm, çağdaş toplumsal yapının parçalandığı, bireylerin simülakr ya da ekran fleneurlarına dönüştüğü bir duruma işaret eder. Kapitalist ekonomik parametrelerin değişmediği bir ortamda, postmodernizmi modernizmin bir sonu ya da ona karşı bir başkaldırı projesi olarak ele almak güçtür. Dolayısıyla Baudrillard, Jameson, Lyotard ve Harvey'in bunu bir durum ya da bir süreç olarak tanımlaması boşuna değildir.

\section{Postmodern Film}

Sanat alanında postmodernizme kayış, modernizmin toplumsal zeminde etkili olan sancılarından kaynaklanmaktadır. Postmodern sanat anlayışı 
içerisinde gündelik yaşam ile sanat ürünü arasındaki ayrışma ortadan kalkmıştır. Her şeyin sanat olabileceği anlayışıyla birlikte yüksek kültür ile popüler kültür arasındaki ayrım yok olmuştur. Üslupta melezleşme hâkim hale gelerek teknoloji ile sanat birleşmiştir (Karadoğan, 2005, s.142). Bu durumun sinemadaki yansıması ise anlatıdaki giriş, gelişme ve sonuç biçeminin erimesi şeklinde gerçekleşmiştir. Bu yeni sinema biçeminde görüntülerin hâkim olduğu ve çoklu anlatım tarzının ağır bastığı bir yapı ortaya çımiştır.

"Postmodern film mi yoksa sinema mı?" tartışması, postmodernizm kavramı üzerinden, sinema alanı içerisinde sorunsallaştırılarak tartışılmaktadır. Ancak postmodernizmin modernizmin içinden çıkan ve gelişen bir durum olduğu düşünülürse, postmodern sinema demek de doğru bir yaklaşım olarak görünmemektedir. Postmodernizm, modernizmin içerisinde biçimlenen bir etki ise, sinema alanında yapılan çalışmalar da bu durumun etkisiyle ortaya koyulan eserler olarak ele alınmalıdır. Dolayısıyla başlı başına bir sinema akımına işaret etmeyen bu filmler için melez bir tür demek daha doğru bir yaklaşım olacaktır.

Postmodernizm tanımlamalarında olduğu gibi postmodern filmler de kalıplar içine sıkıştırılamaz. Postmodern filmler, avangard ve klasik anlatıya sahip filmlerden izler taşısa da, tam anlamıyla bir çerçeve içine oturtulamaz. Postmodern filmlerin belirsizliklerle dolu dili, avangard sinemanın sembolik, metaforik ve çağrışımlarla dolu dilinin pek uzağında sayılmaz. Ancak, avangard sinema sanatsal bir kaygı taşırken, postmodern sinema da böyle bir kaygı mevcut değildir. Dolayısıyla postmodern bir film için her şey sinemasal anlatının içerisinde yer alabilir. Bu filmler, avangard sanatın özelliklerini yıktıkça postmodern olma özelliklerini sağlamlaştırmaktadır (Karadoğan, 2005, s.144-146).

Postmodern filmler, öykü açısından da farklılık taşır. Öykü temelinde klasik bir anlatı takip etmez. Benjamin'in Hikâye Anlatııısı (2012) makalesinde tasvir ettiği ve modernizmle dönüşüme uğrayan hikâye, öznellik ve deneyimden ziyade, kent içinde yakınımızda gelişen anlık olaylara dayanırken, Postmodern öykü ise, ne şimdi ne de geçmişte konumlanır. Ne bireysel ne de tam anlamıla toplumsaldır. Tamamen şimdiyi, geçmişi ve geleceği birbirine karıştıran, bireyleri derinliği olmayan görsel flaneurlara çeviren bir yapıdadır. Çünkü postmodern sinema gücünü, filmsel anlatı ile reel yaşam arasındaki bağlantıyı muğlâklaştırmasından almaktadır. 
Olivier (1997, s.41)'e göre postmodern filmler, birleştirici ve yıkıcı tür olarak ikiye ayrılmaktadır. Birleştirici filmler; klasik anlatıya sahip, bazı karakterleriyle özdeşim kurulmasına imkan sunan, postmodernizmin yüzeyselliğini aşmayan ve herhangi bir eleştiri kaygısı taşımayan filmlerdir. Yıkıcı tür ise, sorgulayıcı ve eleştirel nitelikler taşır. Bu bağlamda bu çalışmanın araştırma nesnesini oluşturan Dövüş Kulübü filmi, hem birleştirici hem de yıkıcı türden özellikler taşımaktadır. Tüketim kültürü eleştirisi ile yıkıcı fakat karakterlerin bazı tavırlarıyla özdeşim kurulabilmesi noktasında birleştirici'dir.

Bunun dışında, üç kategoriye ayrılan bir başka sınıflandırma biçimi daha vardır. Sanatsal nitelik taşıyan, zamanı ve mekânı sorunsallaştıran anlatı yapısını kırılmalara uğratan, kurmaca ve oyun nitelikleri barındıran sanatsal tür, tamamen izlenme kaygısı taşıyan ticari tür ve iki türün niteliklerini de taşıyan melez tür. Berlin Üzerinde Gökyüzü filmi sanatsal türe, Robocop ve Temel İçü̈dü filmleriyse ticari türe, Ucuz Roman (Karadoğan, 2005, s.149) ve çalışmamızın konusunu oluşturan Dövüş Kulübü filmleriyse melez türe örnek oluşturmaktadır.

Postmodern filmlerde anlatı, öykü ve söylem olmak üzere ikiye ayrılır. Öykü; olaylar, karakterler ve eylemler zinciri boyunca işleyen anlama karşılık gelirken söylem ise, kurmaca dünyanın mantığını ortaya koyan olay örgüsünü, zaman kullanımını ve içeriği ileten araçları kapsamaktadır (Chatman, 1990, s.9). Klasik anlatıda giriş, gelişme ve sonuç şeklinde ilerleyen hikâye, postmodern biçemde karışık ilerleyebilir, tersten gidebilir ya da kesilebilir. Dövüş Kulübü'nün başlangıç sahnesi, aslında filmin son sahnesidir. Postmodern yapımlarda, klasik anlatıda olduğu gibi seyircinin kahramanlarla özdeşim kurması güçtür. Dövüş Kulübü'nün başlangıcında Anlatıcıyla kurulan bağ, kısa sürede kırılmaya uğrar. Klasik anlatıların sağladığ1 narsistik özdeşleşme, postmodern filmlerde anti-narsist bir özdeşime dönüşmektedir (Karadoğan, 2005, s.153).

Postmodern filmler, cinselliği (şiddet içeren pornografik bir cinsellik) ön plana çıkartır (Karadoğan, 2005, s.153). Dövüş Kulübü'nde Marla ve Tyler'ın birlikte olma sahneleri bunun örneğidir. Postmodern filmlerde şiddet normalleştirilir. Dövüş Kulübü'nde da bolca kan dolu şiddet sahnesi yer alır. Bu akıma ait filmlerde kahramanlar, genelde orta sinıf ya da alt sinıftan insanlardır ve kötülükle bir ilişkileri mevcuttur (Karadoğan, 2005, s.154). Anlatıcının orta sınıfı temsil etmesi ve Tyler'ın da kötü işlerle uğraşması bu duruma örnektir. 


\section{Postmodernizm ve Özne Bağlamında Dövüss Kulübü Filminin Okuması}

Çalışmanın çözümleme kısmını oluşturan Dövüş Kulübü filmi, sürekli tüketim toplumu ve kapitalizm üzerinden okunmaktadır. Aslında David Fincher'ın Dövüş Kulübü, postmodern filmler içerisinde farklı bir yerde durmaktadır. Filmin vermek istediği mesaj ve kurgusal özellikler, Mavi Kadife ve Antichrist gibi postmodern filmlerde sunulan net göstergelere sahip değildir. Dolayısıyla Dövüss Kulübü, postmodern filmlerin kurgusal özelliklerinden farklı olmasının yanında özne ile ilgili sorunlara odaklanması açısından da postmodern anlatıların karmaşıklığına sahiptir.

Postmodern film anlatılarında tercih edilen psikanalatik derinlik ve karmaşıklık, Dövüş Kulübü filminin yanında Matrix, Pi ve Amerikan Güzeli gibi filmlerde de bir ekol oluştururcasına yer almaktadır (Clark, 2001, s.412-413). Bu filmlerde özellikle karakterlerin parçalanmış benlik problemleri ${ }^{1}$ ve özne meseleleri derinlikli bir anlatımla yansitılmaktadır.

Dövüş Kulübü, sahip olduğu derinlikli anlatısının temelinde bilinçdışı ve bilincin kavgasına odaklanmaktadır. Tam olarak bu kavga postmodernizmin toplumsal dışavurumuna karşlık gelmektedir. Çünkü Freud'a göre (2013, s.46), toplumsalın özne üzerindeki dayatmaları, bireyi nevrotikleştirmektedir. Dövüş Kulübü de öznenin geçmişini tüketip, şimdisini de yanılsamaya çeviren sisteme karşı verilen nevrotik bir kavgayı anlatmaktadır.

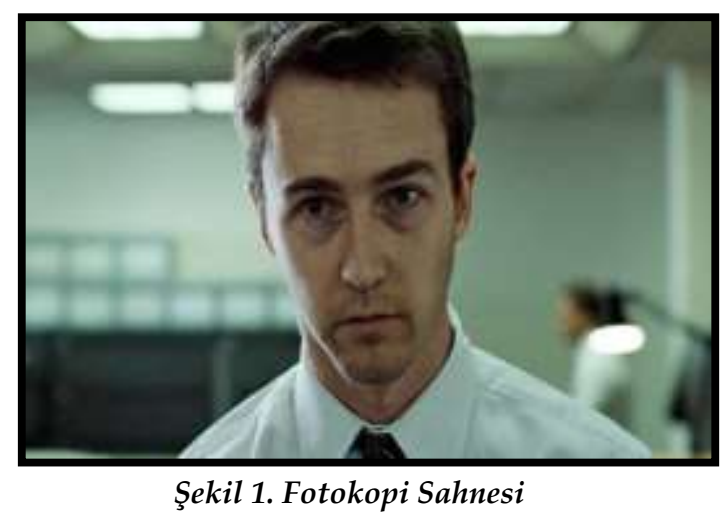

${ }^{1}$ Bu konuda detaylı bir çalışma için Sertalp (2016) "Parçalanmış Benlikler, Parçalanmış Hayatlar ve Parçalanmış Filmler: Bir Dövüş Kulübü Okuması” isimli makaleye bakılabilir. 
Filmde Anlatıcının bir fotokopi cihazının önünde, dördüncü dakikada, "Her şey suretinin suretinin sureti" ifadesini kullanması, filmin sürekli markalara ve reklamlara göndermelerde bulunması, Baudrillard'ın ortaya koyduğu ve Jameson'ında geç kapitalizm olarak tanımladığı çağın; usları yıkmasına, bölmesine, parçalamasına ve öznelerin simülakrlara dönüştüğü bir bilinç kaosuna işaret etmektedir.

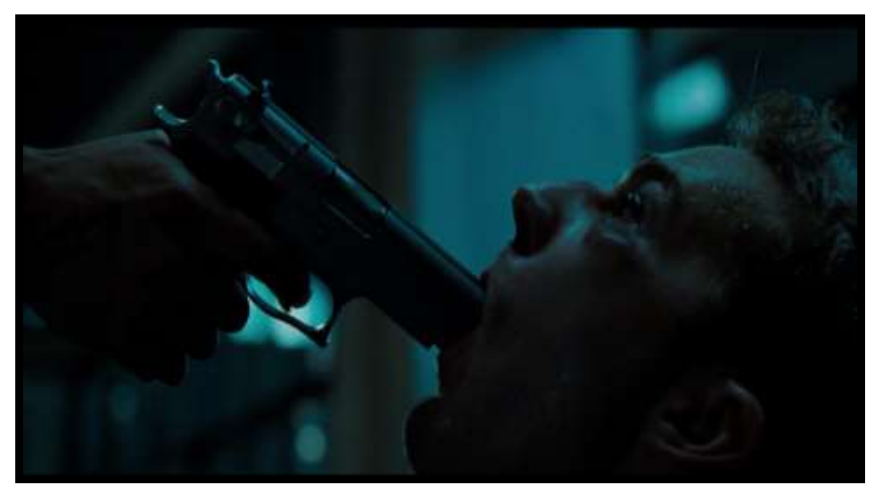

Şekil 2. Açıılış Sekansı

Bu kaos, daha ilk sahneyle izleyiciye hissettirilir. Film, Anlatıcının beyninin içinden geçen bir kamera görüntüsüyle başlayarak izleyiciyi, Tyler'ın elindeki silaha götürür. Fincher, bu sahneyle daha ilk aşamada, bilinçdışı ile ego savaşının ipucunu vermektedir. Ancak, Anlatıcının konuşmaları ve marka görüntüleriyle öykü kesintiye uğratılarak, izleyicinin bu mesajdan uzaklaşmasına ortam hazırlanmaktadır.

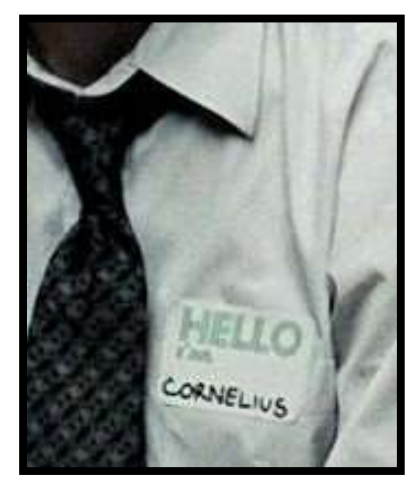

Şekil 3. Yaka Kartı 
Filmde yansitılan ruhsal savaş, yani bir iç savaştır. Fincher, filmde daha ilk sahnelerde bize bunun izini gösterir. Anlatıcının katıldığı ilk terapi sahnesinde taktı̆̆ 1 yaka kartında yazan isim Cornelius'dur. Cornelius, Roma İmparatorluğu döneminde, Kral Cinno'ya karşı bir iç savaş başlatmış ve onu kendi askerlerine öldürtmüştür. Süphesiz Fincher, bu ismi boşuna seçmemiştir. Çünkü Anlatıcı, postmodern bir süreç içinde iç savaş yaşamakta ve buna bağlı olarak da öznesel bir duruş sergileyememektedir. Freud'un oidipus kompleksi, Dövüş Kulübü filminde yansıtılan erillik mücadelesini açıklamaktadır. Tyler ve Anlatıcının kullandığı, "Biz anneleri tarafindan büyütülen çocuklarız" "Babamla dövüşmek isterdim" gibi replikler, babayla ve erillik ile ilgili bir buhrana işaret eder. Çünkü Freud (2013)'e göre kahraman, mitte totemik bir canavar olarak yansıtılan babayı tek başına katleden kişi olarak aktarılmaktadır. Bu mitolojik öyküde erkek çocuklar babalarının sultası altında yaşamakta ve erilliklerinin ispatlamalarına imkan tanınmamaktadır. Eğer erkek çocuklar eril olmak istiyorsa ailenin norm koyucu figürü olan babayı yenmek durumundadır. Freud'a göre toplumsal benliği ifade eden üstben ancak bu şekilde kurulabilir. Eğer erilleşme sağlanamaz ve üstben kurulamaz ise, çocuk için nevroz kaçınılmazdır. Dolayısıyla Tyler'ın "Biz ne büyük buhran gördük ne de büyük savaşı, bizim savaşımız ruhani bir savaş" repliği, üstben krizinin ortaya çıkardığı nevroza dayalı bir ruhsal mücadeleye işaret etmektedir. İkinci Dünya Savaşı, çocukların babasız kalmasına yol açarak, bu şekilde büyüyen çocukların ruhsal olarak erilleşememesine neden olmuştur. Çocuk frustrasyonlarını, annenin söylemiyle babanın adına bağladığında, kültürün düzenine doğru çekilmiş olur. Eğer anne babaya gönderimde bulunmazsa, çocuk ruhsal gelişimini tam olarak neticelendiremez, imgesel ilişkide takılıp kalarak bir psikozun içine düşer (Kızıltan, 1998). Lacan'ın bu vurgusu, Dövüş Kulübü'nde kullanılan baba odaklı söylemleri ve yaşanan ruhsal mücadeleyi açıklamaktadır. Anlatıcının ve Dövüş Kulübü'nün diğer üyelerinin temel mücadelesinin ruhsal kökleri, babasızlıkta gizlidir. Bu frustrasyon ve psikozun yarattığı etki onları toplumsal bir devrime götürüyor gibi yansıtılsa da geçmişe ve özne olamamaya karşı bir mücadeleden söz etmek daha doğru olacaktır. 


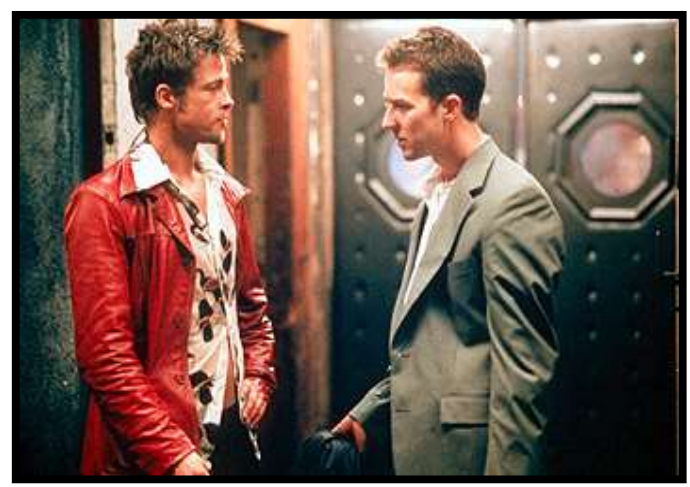

Şekil 4. Tyler ve Anlatıcı

Lacan'ın narsistik döneminde çocuk parça parça tanıdığı beden imgesini, çevresindekilerin bütünsel imgelerinden dolayımlayarak birleştirir. Bu birleştirme ve oidipus (annenin babayı dilbilimsel bir gösterenle işaret etmesi) sayesinde, ego kurulur. (Kızıltan, 1998). Bilinçdışının ego üzerinde hâkimiyet kurması ya da yerine geçmesi çocuğun simgesel olarak baba figüründen uzak kalması neticesinde gerçekleşir. Filmde, Tyler'ın Anlatıcıyı ele geçirmesinin nedeni budur.

Tyler'ın Anlatıcıyı ele geçirme sürecinde Fincher, reklamcılık tecrübesinden kaynaklı subliminal mesaj yöntemi ve sinemanın yirmi beşinci kare tekniğiyle hem Anlatıcının bilinçdışına hem de izleyicinin bilinçdışına bu karakteri adım adım yerleştirir. Tyler, bu yöntemle beş karede belirir. Bu belirmelerin ilki, "Her şey suretinin suretinin sureti" repliğinin yer aldığı sahnede (üçüncü dakikanın elli altıncı saniyesi), ikincisi, doktorun Anlatıcıya tavsiyede bulunduğu sahnede (altıncı dakikanın üçüncü saniyesi), üçüncüsü, testis kanseri olan hastaların terapi sahnesinde (yedinci dakikanın on beşinci saniyesi), dördüncüsü, Marla'nın uzaklaşırken Anlatıcının sokakta onu izlediği sahnede (on ikinci dakikanın dördüncü saniyesi) son olarak ise, Anlatıc yürüyen merdivendeyken (on sekizinci dakikanın elli beşinci saniyesinde) gerçekleşir. Bu sahnelerde yönetmen, Tyler'ın görüntüsünü her aşamada daha fazla ekranda tutar. Bunların dışında, Anlatıcının Bob'un göğüsünde ağladıktan sonra oluşan yüz şekli (sekizinci dakikanın elli dördüncü saniyesinde) Tyler'ın yüzüne benzemektedir. Tüm bunlar Anlatıc1nın postmodernite içerisinde özne olarak var olma arayışına işarettir. 


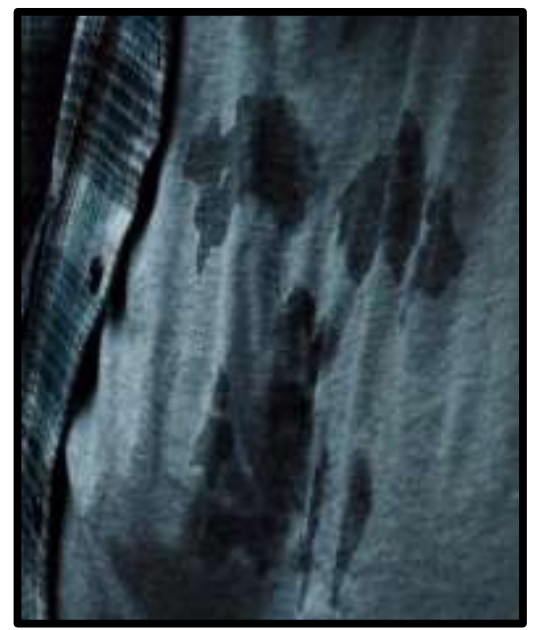

Şekil 5. Oluşan Yüz Şekli

Anlaticının Tyler'ı telefonla araması ve Tyler'in telefona yanit vermeyerek Anlatıcıya "Ben gelen çağrıları yantlamam geri dönüş yaparım" ifadesini kullanması onun Anlatıcının bilinçdışı olduğuna işarettir. Çünkü psikanalatik yaklaşıma göre ego, bilinçdışına erişemezken, bilinçdışı egoya ulaşabilmektedir. Filmde Anlatıcının katıldığı terapi grubunun isminin testis kanserlileri olması ve bu terapide çocuğu olmadığı için karısının kendisini terk ederek başka birisiyle evlendiğini anlatan bir karaktere yer verilmesi filmin vermek istediği cinsellik ve bilinçdışı mesajlarının ipuçları arasında yer almaktadır (Horzum, 2011 s.15).

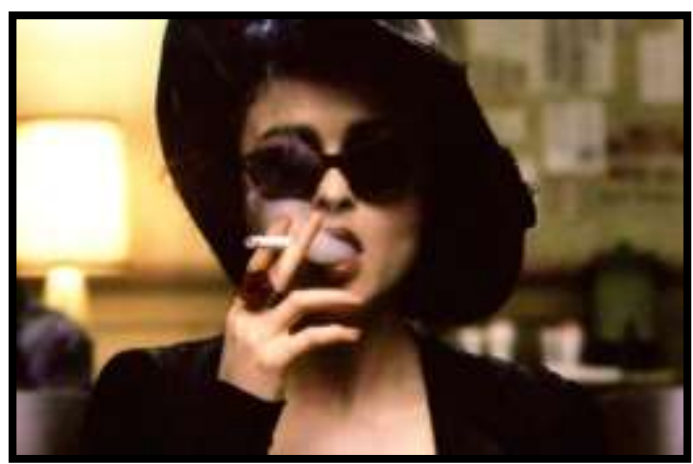

Şekil 6. Marla Karakteri 
Buna ek olarak, Marla karakterinin de anlatıda ikinci planda kalması, verilen mesajı sağlamlaştırmaktadır. Çünkü uygarlık erkek egemen bir toplumsal yaratarak kadınlarla erkeklerin arasına bir sınır çizmektedir. Erkeğin toplumsal mücadelesi, libidosunu kadınlardan geri çekmesine neden olmaktadır (Freud, 2013, s. 61). Anlatıcının evinin havaya uçtuğunu anlatması üzerine, Tyler'ın "Daha da kötüsü olabilirdi. Bir kadın penisini kesebilirdi" söyleminde bulunması ve erkek egemen dönem olarak nitelendirilen avcllık ve toplayıcılık çağından bahsetmesi bir yandan libidonun bastırılmasına bir yandan da erkek egemen eril dönemin arzulandığına işaret etmektedir. Buna ek olarak Anlatıcının "Tüm bunlarm Marla isimli bir kızla ilgisi vardı" sözü ve Tyler'ın Anlatıcıyı tamamen ele geçirdikten sonra, yaptıkları eylemlere ve kurdukları Dövüş Kulübü'ne Marla başta olmak üzere, hiçbir kadının alınmaması da bu teorik çerçevede verilen bir başka mesajdır. Ayrıca, Anlatıcının Marla'nın evinin önünde Bob ile konuşurken duvarda "I have Myself" yazısının yer alması, erillik ve dişillik bağlamında özneye göndermede bulunmaktadır.

Cinselliği özgürce yaşayan Tyler'dır. Çünkü Anlatıcı yani ego erilleşememiştir. Bilinçdışında yer alan id ise, arzuları için sınır tanımaz. Anlatıcı rüyasında, Marla ile birlikte olduğunu görür fakat uyandığında Marla ile birlikte olan Tyler'dır. Bu sahne Tyler'ı bilinçdışı, Anlatıcıyı da ego olarak imlemektedir. Rüya ise, bilinçdışının dışavurumu ve öznenin maruz kaldığ 1 bir durumdur (Lacan, 2013, s.8). Özne, rüyalarında akışı yönetemez ama anlatının ilerleyişini takip eder. "Rüyanın faili bilinç değil; bilinçdışının öznesidir". Ayrıca, "İdeolojiye bilinçli olmakla karşı çıkılmaz; aksine özneyi ideolojiye dahil eden ve bilinçdışını arzudan uzaklaştıran bizzat bilincin kendisidir" (Mcgowan, 2012 s. 41, 43). Anlatıcının Tyler ile tanıştıktan sonra sisteme ve onun yarattığı etkilere başkaldırısı bilincin etkisini yitirerek bilinçdışının öne çıkmasıyla mümkün olmuştur. 


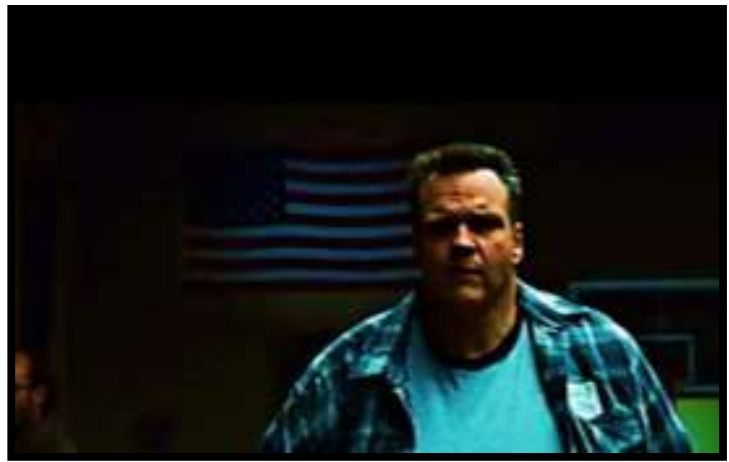

Şekil 7. Renkleri Canlı ve Temiz Amerika Bayră̆ı

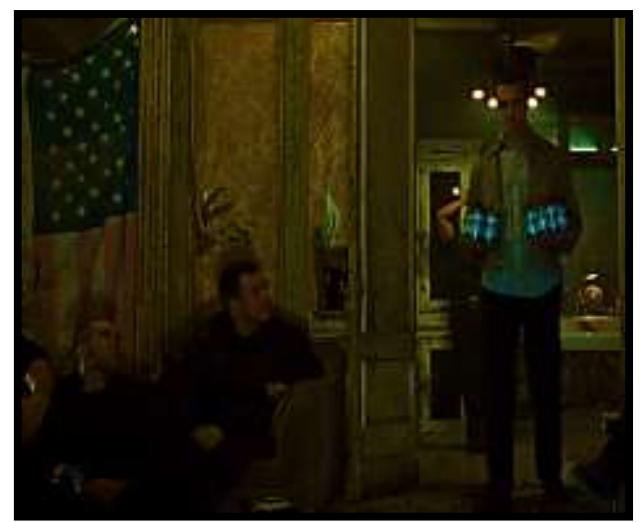

Şekil 8. Renkleri Solgun, Kirli ve Kırışık Amerika Bayrağı

Bilinçdışı ile ego savaşının devam ettiği iki sahnede, Amerikan bayrakları dikkat çekmektedir. Filmin başlarında, terapi sahnesinde, renkleri canlı ve temiz bir Amerikan bayrağı yer alırken, filmin sonlarına doğru bir diğer sahnede, sisteme karşı yaptıkları eylemleri haberlerde gururla izlerlerken odada yer alan eskimiş, soluk ve kirli bir Amerikan bayrağı dikkat çekmektedir. Yönetmen burada bir ironi yapmaktadır. İlk sahnede bayrak canlı ve kusursuzdur. Çünkü sistem, erkekleri erillikten ve özne olma durumundan uzaklaştırarak görevini yerine getirmiştir. Diğer sahnede bayrak; eski, soluk ve kirlidir. Çünkü Dövüş Kulübü üyeleri; sistemin yarattığ1 simülasyonun içerisinden çımış, modernizme karşı erilliklerini kazanmak ve gerçek bir özne olabilmek için savaş başlatmıştır. 
Tyler'ın "Acı gerçeğin tek kaynağıdır." ifadesi özne olabilme mücadelesi veren bireylerin hakikate giden yolda acıyla tanışmaları gerektiğine dair bir mesaj sunmaktadır. Eğer hakikate ulaşmak isteniyorsa, Anlatıcı bilinçdışıyla acıya dayanan ruhsal bir mücadele vermelidir. Filmde aşırı şiddet, kan ve acı barındıran kavgalar; aslında ruhsal acıdan geçerek hakikate ulaşma çabasıdır. Tarkovsky'nin İz Sürücü filmindeki İz Sürücü ve Dostoyevski'nin Yeraltından Notlar kitabında yer alan Yeraltı İnsanı karakteri, hakikate giden yolda arzuyu başrole koyarken Fincher ise, acıyı koymuştur. Filmde Tyler'in sabun imal etmesi ve sabunun hem temizlik hem de patlayıcı olma özelliğinin olması yıkıcı bir temizlik iması taşımaktadır. Tyler'ın "Dibe vurmanın kutsallı̆̆ı" sözü yine bu türden bir temizliğe işarettir. Yıkıcılık ve dibe vurma gibi ifadeler, postmodern bireyin öznesel problemlerine karşllık gelmektedir.

Filmin sonunda Fincher, son bir subliminal mesaj ile güçsüz, kesik ya da sertleşmemiş bir fallus göstererek bilinçdışının ego tarafından bastırıldığına işaret etmektedir. Gökdelenlerin yıkılışı genellikle kapitalist sistemin yıkılışı olarak algılanmaktadır. Freud'un bastırılmış bilinçaltı dürtülerinde sembolize ettiği sivri şeyler ve gökdelenler erkeklik organını temsil ediyorsa, gökdelenlerin yıkılışı (Horzum, 2011 s.17), dişilliğe karşı savaşın, bilinçdışının bastırılmasıyla ertelendiğinin mesajını oluşturmaktadır.

\section{Sonuç}

Bilinçdışını temsil eden Tyler ile egoya karşılık gelen Anlatıcının kavgasıyla başlayan ve sonrasında toplumsal bir örgütlenmeye giden Dövüş Kulübü; starbucks bardakları, ikea katalogları ve çeşitli marka göndermeleriyle kapitalizm eleştirisi yaparken, anlatısının daha derinine inildiğinde psikolojik unsurlar barındırdığı görülmektedir. Tyler ve Anlatıcının otobüste giderken Gucci reklaminda yer alan modern erkek resmine karşı getirdikleri "Erkek böyle mi olmalı" cümlesi, modanın erkekleri belirli kalıpların içine sokmaya çalıştığına dair ince mesajlar vermektedir. Film; reklam, tüketim, moda, araçsallaşan akıl, hesaplanabilirlik, yanılsama ve öznenin parçalanmışlığı gibi temel sorunlara dikkat çekerek bir modernizm eleştirisi yapmaktadır.

Ancak anlatının derinlikli yapısı pskianaliz temelinde çözümlendiğin de ortaya çıkan özne merkezli mesajlar, Dövüş Kulübü filminin klasik bir anlatının ötesinde modernizmin yarattığı ruhsal sarsıntılara odaklandığını gös- 
termektedir. Filmde Tyler, postmodern süreç içerisinde parçalanmış benliklere, özne olarak tutunamamaya ve erkek egemen toplumsalın erkek benliği üzerinde yarattığı eril etkilere karşı bir başkaldırı da bulunmaktadır. Anlatı$\mathrm{Cl}$ ise, toplumsal yapıya uyum sağlamaya çalışan ama bu yükü de tam olarak kaldıramayan modernizm içerisinden çıan postmodern sarsıntılara karşılık gelen bir şizofreniye işaret etmektedir.

Dövǚs Kulübü'nün anlattı̆g bu şizofreni, günümüzde daha da acımasız bir biçimde yoluna devam etmektedir. Bugün, kapitalizmin orta sınıfı ortadan kaldırarak, zengin ve fakir olmak üzere toplumları iki sınıfa indirgediği ve bu iki sınıf arasında uçsuz bucaksız gelir eşitsizliğinin olduğu bir yapı mevcuttur. Ekonomik eşitsizlik, bireyin ruhsal anlamda varoluşunu engel teşkil etmektedir. Filmde Anlatıcının babasız büyüdüğü için erilleşememesi ve vahşi kapitalizmin merkezinde çektiği özne olamama problemi, günümüzde de şiddet ve intihar gibi olaylarla etkisini hissettirmektedir.

Ekonomik adaletsizlik, toplumsal adaletsizliğin temelini oluşturur. Toplumsal adaletten yoksunluk, psikolojik gelişim eşitsizliğine dönüşür. Dolayısıyla bizler, her gün yeniden üretilen bir nevrozun içine uyanırız. Filmde, Anlatıcının uyku sorunu için "İnsan uykusuzluk çekerken hiç uyumuyor ve hiçte uyanık kalamıyor" sözü, günümüz için de geçerlidir. Günümüz insanı, bilincinin açı mı ya da kapalı mı olduğunun belli olmadığı bir ruhsal karmaşanın tam merkezinde yer almaktadır. Baudrillard'ın suretler dünyası olarak tanımladığ 1 bu ortam, giderek hepimizi Dövüş Kulübü'nün Anlatıcısına dönüştürmektedir. Aramızda borderline kişilikler çoğalmakta ve egonun, id ile süperego arasında sağladığı denge aksamaktadır.

İçinde yaşadığımız bu yapı, benliklere zarar vererek kamusal alanların ayrışmasına ya da niteliksel anlamda kamusal alan olmaktan uzaklaşmasına neden olmaktadır. Richard Senett'in Kamusal İnsanın Çöküşü (2013) adlı çalışmasında bahsettiği kişilerin davranış değişimlerinin örnekleri Dövüş Kulübü'nde görülmektedir. Bu da Dövüş Kulübü'nün özne, hakikat, toplumsal değişim, kimlik sorunu, kültür endüstrisi ve ruhsal buhranlar gibi pek çok alana değinen postmodernist kalıpların ötesinde önemli bir film olduğunu ispatlamaktadır. 


\title{
EXTENDED ABSTRACT
}

\section{Postmodernism and Evaluation of the Film of Fight Club in the Context of Subject}

\author{
Anıl Kaan Uçar \\ Ordu University
}

To understand postmodernism, it is extremely important to consider modernism first. Modernism, in its clearest sense, covers the period starting from the Age of Enlightenment until the end of the Second World War, where national currents also strengthened. Modernism that influenced the social, political and economic processes that developed in the West in the 18th century with a progressive and rational perspective; He predicted that the individual can overcome everything with his mind, become individual by consuming, and rise by working hard and competing. This reductionist and homogenizing attitude of modernism has dragged individuals intelligently and emotionally into chaos. This chaos paved the way for subject divisions, economic inequalities, weakening of identities and the disappearance of time and space phenomena as a result of urbanization. As long as these effects of modernism surround the social, postmodernism has affected all branches of art. Especially in the context of cinema, 1990s were the years when postmodern films started to become widespread. Against the social environment created by modernism; Postmodern films that go beyond other films at the point of transferring violence, fragmentation, turmoil and sexuality are far from the classical narrative style. The story that progresses in the form of introduction, development and conclusion in the classical narrative can progress from the end to the end or be cut in the postmodern film. Violence is normalized in postmodern films.

This study, which deals with the Fight Club film, which includes these features, in the context of the problem of postmodernism and non-subject, has evaluated the film's deep narrative in the context of consciousness and unconscious cases. The spiritual warfare reflected in the film is a civil war. Fincher shows us the trail of this in the early stages of the movie. Cornelius is the name written on the name badge he wore in the first therapy scene 
that the narrator participated. Cornelius started a civil war against King Cinno during the Roman Empire and killed him to his own soldiers. Of course, Fincher did not choose this name for nothing. Because the Narrator experiences a civil war in a postmodern process and, accordingly, is unable to take a subjective stance. Freud's oedipus complex explains the masculinity struggle reflected in the movie Fight Club. The lines used by Tyler and the Narrator, "We are the children raised by their mothers", "I would like to fight my father," point to a crisis about father and masculinity. "We have neither seen the great depression nor the great war, our war is a spiritual war", says Tyler's spiritual struggle based on neurosis caused by the crisis of the superior. In addition, the narrator calls Tyler on the phone and Tyler uses the answer to the narrator, saying, "I answer the incoming calls, I will come back," is a sign that the narrator is unconscious. Because, according to the psychoanalytic approach, the ego cannot reach the unconscious while it can reach the unconscious ego.

In the film, a link is established between truth and pain in the background of discourse and vision. "Pain is the only source of truth." The expression provides a message that individuals struggling to become subjects should meet pain on the way to the truth. If the truth is desired, the Narrator must fight the unconscious spiritually based on pain. Fights with extreme violence, blood and pain in the movie; it is actually an effort to reach the truth through spiritual pain. The character of the Underworld in Tarkovsky's Trace Driver, Trace Driver and Dostoevsky's Notes from the Underworld, put the desire on the road to truth, while Fincher put the pain. In the film, Tyler's soap production and soap are both cleaning and explosive features imply destructive cleaning. Tyler's promise of "the holiness of hitting the bottom" again marks this kind of cleanliness. Expressions such as destructiveness and bottoming correspond to the subjective problems of the postmodern individual.

As a result, the Fight Club, which started with the fight of the Narrator, who represents the unconscious, and the ego corresponding to the ego, and then goes to a social organization; While criticizing capitalism with starbucks glasses, ikea catalogs and various brand references, the psychological elements draw attention when the narrative goes deeper. In the film, Tyler also has a revolt against the disintegrated selves in the postmodern process, the inability to hold on as a subject, and the masculine effects of the male 
dominant social on the male self. The narrator points to a schizophrenia corresponding to postmodern tremors that emerge from modernism, which tries to adapt to the social structure, but cannot fully lift this burden. This schizophrenia described by the Fight Club continues on its way even more brutally today. Today, there is a structure where capitalism weakens the middle class, reduces the societies rich and poor to two classes, and there is an immense income inequality between these two classes. Economic inequality impedes the spiritual existence of the individual. In the film, the problem of the narrator's being unable to become masculine because he grew up without a father and not being a subject at the center of the wild capitalism still makes an impression with the events such as violence and suicide.

\section{Kaynakça / References}

Baudrillard, J. (1998). Simülakrlar ve simülasyon. (O. Adanır, Çev.). İstanbul: Doğu Bat.

Bayraktaroğlu, A., M. ve U., Uğur. (2011). Postmodern sinemada filmlerarasılık bağlamında pastiş ve parodi. Süleyman Demirel Üniversitesi Güzel Sanatlar Fakültesi Hakemli Dergisi, 7, 1-20.

Benjamin W. (2012). Son bakışta aşk. (N. Gürbilek, Çev.) İstanbul, Yapı Kredi Yayınları.

Best, S. ve D. Kellner (2011). Postmodern teori. (M. Küçük, Çev.). İstanbul:Ayrıntı Yayınları.

Büyükdüvenci, S. ve S., R., Öztürk. (1997). Postmodernizm ve sinema. Ankara:Ark Yayınları.

Chatman, S. (1990). Coming to terms: The rhetoric of narative in fiction and film. London:Cornell University Press.

Featherstone, M. (1996). Postmodernizm ve tüketim kültürü. (M. Küçük, Çev.). İstanbul:Ayrintı Yayınları.

Fincher, D. (Yönetmen). Dövüş kulübü [Sinema Filmi]. ABD.

Freud, S. (2013). Uygarlı̆̆ın huzursuzluğunda (Çev: Haluk Barışcan). İstanbul: Metis.

Harvey, D. (1997). Postmodernliğin Durumu. (S. Savran, Çev.). İstanbul:Metis Yayınları.

Horzum, I. (2011). 'Dövüş kulübü' filminin ruhbilimsel çözümlemesi. Akademik Bakış Uluslararası Hakemli Sosyal Bilimler E-Dergisi, 25, 1-24.

Jameson, F. (1994). Postmodemizm. (N. Plümer, Çev.). İstanbul, Yapı Kredi Yayınları. 
Karadoğan A. (2005). Postmodern sinema mı film mi?. Ankara Üniversitesi İletişim Fakültesi Illetişim Araştırmalarn Dergisi 3, 133-160.

Kızıltan, H. (1998). Jacques Lacan ve psikanaliz. Eleştirel Psikoloji Bülteni. 15 Aralık 2019 tarihinde, http://www.elestirelpsikoloji.org/eleps/eleps/kiziltan.html adresinden erişildi.

Lacan, J. (2013). Fallus'un anlamı. (S., M. Tura, Çev.). İstanbul:Alt Kırk Beş Yayın. Lyotard, J. F. (1994). Postmodern durum. (A. Çiğdem, Çev.). Ankara, Vadi Yayınları. McGowan, T. (2012). Gerçek bakış. (Z. Barkot, Çev.). İstanbul, Say Yayınları.

Olivier, B. (1997).Modernite, modernizm ve postmodernist film: Verhoeven'in temel içgüdü'sündeki yüzeysellikler. Büyükdüvenci, S. ve S., R., Öztürk (Der), Postmodernizm ve Sinema içinde (s. 31-54). Ankara, Ark Yayınları.

Sarup, M. (1995). Postyapısalcllk ve postmodernizm. (A. Güçlü, Çev.). Ankara, Ark Yayınevi.

Senett, R. (2013). Kamusal insanın çöküşü. (S. Durak ve A. Yılmaz, Çev.). İstanbul, Ayrint Yayınları.

Sertalp, E. (2016). Parçalanmış Benlikler, parçalanmış hayatlar ve parçalanmış filmler: Bir dövüş kulübü okuması. Moment Dergisi 3(2), 385-408.

\section{Kaynakça Bilgisi / Citation Information}

Uçar, A. K. (2020). Postmodernizm ve özne bağlamında dövüş kulübü filminin değerlendirilmesi. OPUS-Uluslararası Toplum Araştırmalarn Dergisi, 16(28), 1541-1561. DOI: 10.26466/opus.676541 